Rupantaran : A Multidisciplinary Journal

Vol. III : 93-107, March, 2020

ISSN : 2091-0061

Research Management Cell (RMC)

Dhankuta Multiple Campus, Dhankuta

Tribhuvan University, Nepal

\title{
Disasters: Spatio-Temporal Distribution of Dhankuta District, Nepal
}

\author{
Tika Ram Linkha ${ }^{1}$ \\ Email: tika.linkha@gmail.com
}

\section{Abstract}

This paper attempts to analyze the temporal and spatial distribution of disaster in Dhanktua district, Nepal. It provides information regarding when and where the disasters have mostly occurred in Dhankuta. Disaster can occur at any time at anywhere although every disaster has a temporal and spatial dimension which helps to predict the future events In this context, this paper provides the history and trend of disasters in Dhankuta. This paper is based on mostly secondary data extracted from the Ministry of Home Affairs, Disaster Risk Reduction (DRR) Portal. To analyze this, mostly descriptive methods has been applied where the quantitative method also applied for the reflection of disaster data. Fire, landslide, heavy rainfall and thunderbolt were the major disasters that frequently occurred in this district during 2017-2019. It is found that fire incidents were frequently occurred in the month of March, the landslide in July, heavy rainfall in July and thunderbolt in April. It is interesting that, those years where the incidents of fire were higher the incidents of the landslide were low and vice versa and there is a positive relationship between landslide and heavy rainfall. This study will important to local levels and relevant agencies for disaster preparedness because the impact of the disaster is based on the level of preparedness. This analysis is based on limited data which covered 10 March 2017 to 31 December 2019. This study provides a new perspective in the field of disaster where temporal and spatial dimensions are considered.

Key Words: Disaster, landslide, fire, thunderbolt, temporal, spatial

\section{Introduction}

The prevalence of disasters can be traced to the beginning of human civilization (Bankoff, 2004). However, the distribution of disasters is varying according to the geology, topography, slopes, aspects and climatic factors of a specific landscape.

1. Mr. Linkha is a Lecturer of Geography at Tribhuvan University, Dhankuta Multiple Campus, Dhankuta. 
Gilbert F. White was the pioneer scholar for the study of natural hazards in academia then his other colleagues also contributed regarding on this. They promulgated a research paradigm that involved assessing risk from a natural event, identifying adjustments to cope with the hazards, determining people`s perception of the event, defining the process by which people choose adjustment and estimating the effects and public policy on the process (Shrestha, 2005). Mitchell et al., (2008) also argue that the late Gilbert F. White pressed the geographic community on the issues of natural hazards with no uncertain terms.

Natural hazards are the continuous process on the earth's surface and not allnatural hazards are considered to be a disaster. A hazard can only be a disaster when the event causes significant damage to life and property (ICIMOD, 2007). A disaster is an adverse situation that overwhelms the capacity of people to protect their lives and livelihoods, and in most instances, it requires external help in dealing with the losses (Practical Action, 2010). Disasters, especially those that seem principally to be caused by natural hazards (Wisner, Blaikie, Cannon, \& Davis, 2005). Those natural process which poses a threat to human life or property known as natural hazards. However, a hazard is a natural disaster when the event causes significant damage to life or property (Hyndman \& Hyndman, 2017).

The impact of a disaster can vary based on the type and frequency of the disaster and other socio-economic factors, level of preparedness prevalent in the area (Gajanayakea et al., 2018). Developing countries have an increasing number of deaths caused by natural disasters whereas, developed countries have greater economic losses (Keller et al. 2015; Hyndman \& Hayndman, 2017; Khanal, 1996). This is because people of developing countries are living in marginal and hazardous land on steep slopes and near the river and their houses are also constructed poorly which makes it difficult to evacuate in the case of disasters. In addition, rapid growth in population and increasing poverty and adoption of technology without importing the complete packages of surroundings safety measures such as insurance, physical defense, hazard assessment, monitoring and mapping have caused the countries more vulnerable for hazards. For example, the Northridge earthquake in Los Angeles in 1994 caused \$2030 billion in property damage whereas only 60 people died. The next great earthquake that occurred in California could cause more than $\$ 100$ billion in damage. Likewise, the tsunami in the Indian Ocean in December 2004 killed nearly 223000 people. In comparison, the tsunami in the North Pacific in 1964, although equal in size, killed only 119 people (Keller, Devecchio, \& Clague, 2015).

Natural disasters are serious events that disrupt the functioning of a community and it caused widespread hardship. It contributes significantly to the loss of life and damage to property. Disaster is a function of hazard, level of vulnerability and the 
ability of a community to cope with potential risk in a particular geographical setting (Pearce, 2003). Approximately, 265 million people have been displaced due to natural hazards since 2008. In addition, more than 17 million people were internally displaced in 2018 alone (Francis, 2020). Since 1974, about 2.5 million people have killed caused by natural disasters worldwide (Hyndman \& Hyndman, 2017). The average annual loss of life and financial loss has been around 150000 and 50\$ million per year respectively (Keller, Devecchio, \& Clague, 2015). The number of recorded events of natural hazards has increased in the last 50 years (Leroy, 2006). Khanal (1996) also claimed that the losses from hazards have increased three folds in the world in the last two decades.

In such circumstances, this paper aims to explain the temporal and spatial distribution of disaster at Dhankuta district, Nepal and its socio-economic impact briefly. There are various studies related to disasters in Nepal although still lack of study to connect disasters with the time period and places. Hence, this paper attempts to portray the relationship between disasters with time and places. This information will be helpful for the entire local levels and other concerning agencies of Dhankuta district to prevent future disasters. The impact of disasters is exacerbated by the lack of preparedness and the absence of measures for mitigating their impact. So, the results of this paper will be the foundation for disaster risk reduction at Dhanktua district in particular and Nepal in general.

\section{Methods and Materials}

\section{Study area and data}

Dhankuta district is purposively selected for the analysis of the distribution of disaster events. The study area lies in the province number 1 (It does not get its name till the date), eastern hills of Nepal.

Geographically it is extending from $26^{\circ} 53^{\prime}$ to $27^{\circ} 19^{\prime}$ northern latitude and $87^{\circ}$ $08^{\prime}$ to $87^{\circ} 33^{\prime}$ ' eastern longitude. Nowadays, the district has been restructured into seven local government units including three municipalities and four rural municipalities (Figure 1) after the promulgation of the new federal constitution of Nepal, 2015. As per the constitution, the Nepal government formed a Local Level Restructuring Commission (LLRC) in national level to recommend the

LOCATION MAP OF DHANKUTA DISTRICT

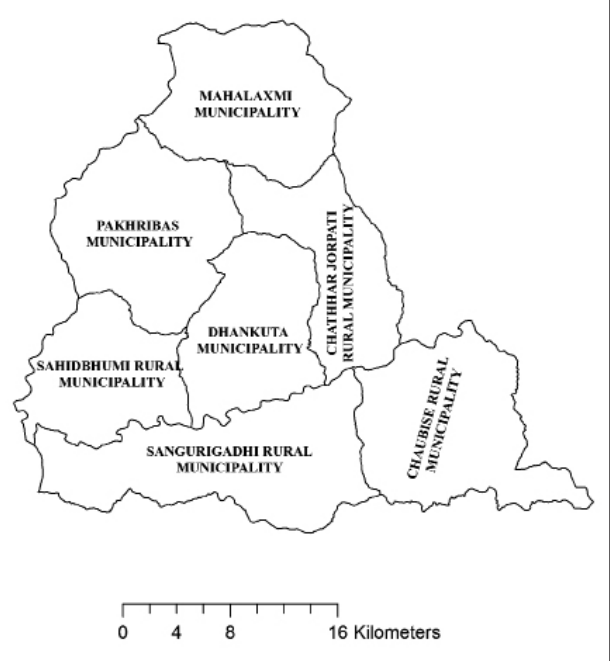

Fig. 1: Local Levels of Dhankuta 
numbers, name, boundary and center of each local level. According to the Terms of Reference (ToR) approved by LLRC, each district has District Level Restructuring Technical Committee (DLRTC) in every district under the chairmanship by Local Development Officer (LLRC, 2073). This committee recommended to LLRC regarding the number, name, center and the boundary of each local level after the consultation with entire political parties and civil societies from entire districts of Nepal. Then, the LLRC compiled, verified and revised in minor cases and submitted its report to Government. Then, the Nepal government made decision and published in Nepal Gazette dated 10 March 2017 which formally replaced the old VDCs by present local levels (Linkha, 2018). Henceforth, disasters are continuously occurring in this district however, this paper confines the data only after the formation of local governments in Nepal i.e., 10 March 2017 to 31 December 2019. Dhankuta district is purposively selected for the analysis of the distribution of disaster events. The study area lies in the province number 1 (It does not get its name till date), eastern hills of Nepal.

Geographically it is extending from eastern longitude. Nowadays, the district has been restructured into seven local government units including three municipalities and four rural municipalities (Figure 1) after the promulgation of new federal constitution of Nepal, 2015. As per the constitution, Nepal government formed a Local Level Restructuring Commission (LLRC) in national level to recommend the numbers, name, boundary and center of each local level. According to the ToR approved by LLRC, each district has District Level Restructuring Technical Committee (DLRTC) in every district under the chairmanship by Local Development Officer (LLRC, 2073). This committee recommended to LLRC regarding on the number, name, center and the boundary of each local level after the consultation with entire political parties and civil societies from entire districts of Nepal. Then, the LLRC compiled, verified and revised in minor cases and submitted its report to Government. Then, the Nepal government did decision and published in Nepal Gazette dated on 10 March, 2017 which formally replaced the old VDCs by present local levels (Linkha, 2018). Henceforth, disasters are continuously occurring in this district however, this paper confines the data only after the formation of local governments in Nepal i.e., 10 March, 2017 to 31 December, 2019.

\section{Data sources and generation}

This paper is mainly based on secondary data sources. The data were taken from Nepal Disaster Risk Reduction (DRR) Portal, the government of Nepal. It is extracted from free access at www.drrportal.gov.np on 11 January 2020. After extracted the necessary data, it was compiled and tabulated into excel format. In addition, short field verification as well as a cross-check of data also done with the data of Nepal Red 
Cross Society (NRCS), Dhanktua and telephone interview with the representatives of local levels. The collected data is analyzed using both descriptive and quantitative methods. The quantitative method has been also used to explain the tables.

\section{Results and Discussions}

\section{Disasters in Nepal}

Nepal is highly prone to multiple hazards because of its diverse topography and climatic conditions, geological positions, rugged topography and steep landscape. Nepal, not only has relatively young mountains and geology but also encompasses around one-third of the world's total 2400 kilometers of the Himalaya. In addition, the subduction of the large Indian plate into the Eurasian (Tibetan) plate has been continually thrusting the Himalayas upwards after its formation, making it geographically unstable which poses Nepal at very risk for various types of disasters (MoHA, 2019). As a result, people of Nepal live with hazards, accepting as a way of life. Disasters have numerous impacts on the various geographic and societal frameworks that people are continuously under the threat of multiple disasters in Nepal. The earthquake of 1934, 1980, 1988, 2015 and the flood of 1993, 2008, 2013, 2014 and 2017 are the example of most devastating disasters which losses to human lives, properties as well as it adversely affected the development process of the country as a whole (MoHA, 2017). In Nepal, the most frequent hazards causing great loss in lives and property are floods, landslides, avalanches, hailstorms, lightning, earthquakes, fire and epidemic (Khanal, Shrestha, \& Ghimire, 2007). So, the global vulnerability presented Nepal as the rank of 20th multi-hazard-prone country, 4th in the case of climate change, 11th is related to earthquake and 30th in terms of flood hazards (Gautam, 2017).

Ministry of Home Affairs (MoHA) working as a focal agency for disaster in Nepal recorded that on an average yearly 872 people have been killed, 1773 injured, 127118 families were affected during 1971-2018 caused by various disasters. Among these, epidemic (40\%) earthquakes (23\%) and landslides (12\%) are the major disasters to kill people that obtained first, second and third positions respectively. The details of the disasters in Nepal are as follows (Table 1);

Table 1: Multi-hazard Scenario of Nepal, 1971-2018

\begin{tabular}{|r|l|r|r|r|r|r|}
\hline S.N. & Types of Disaster & $\begin{array}{c}\text { No. of } \\
\text { Incidence }\end{array}$ & Death & Missing & Injured & $\begin{array}{c}\text { Family } \\
\text { Affected }\end{array}$ \\
\hline 1 & Fire & 12694 & 1755 & 0 & 2176 & 265962 \\
\hline 2 & Lightning & 2143 & 1780 & 129 & 3235 & 7758 \\
\hline 3 & Landslide & 3729 & 5141 & 191 & 2053 & 559347 \\
\hline 4 & Wind storm & 298 & 21 & 0 & 95 & 1718 \\
\hline 5 & Flood & 4368 & 4628 & 87 & 615 & 3726261 \\
\hline
\end{tabular}




\begin{tabular}{|c|l|r|r|r|r|r|}
\hline 6 & Epidemic & 3474 & 16598 & 0 & 44992 & 513409 \\
\hline 7 & Avalanche & 3 & 17 & 4 & 7 & 1 \\
\hline 8 & Snow Storm & 7 & 97 & 7 & 0 & 10 \\
\hline 9 & Hailstones & 134 & 9 & 0 & 24 & 3407 \\
\hline 10 & Earthquake & 175 & 9771 & 0 & 29142 & 890995 \\
\hline 11 & Cold Waves & 438 & 563 & 0 & 83 & 2441 \\
\hline 12 & Others & 1134 & 626 & 13 & 919 & 3214 \\
\hline \multicolumn{2}{|r|}{ Total } & 28597 & 41006 & 431 & 83341 & 5974523 \\
\hline
\end{tabular}

Source: $\mathrm{MoHA}, 2019$

Observing the data of last two years (2017 and 2018), the flood was the major disaster which killed more people which shared $19 \%$ from the total death due to disasters, then the landslide killed $16.6 \%$, the lightning shared $16.5 \%$ and the fire accounted $15.5 \%$ from the total death respectively in all over the country. Remarkably the epidemic killed only 1.5 percent of people during these last two years, however, it was shared a large proportion (40\%) during 1971-2018.

\section{Disasters in Dhanktua}

Nepal is very prone to various disasters due to this complex geophysical condition and poor socio-economic status. So, Nepal is facing numerous disasters that lose huge lives and property. Out of 77 districts in Nepal, it is also one of the hill districts which is highly prone to different disasters due to the topography, geology and climatic factors. According to recent data, the scenario of disaster in Dhankuta are given below (Table 2);

Table 2: Natural Disasters in Dhankuta, 2017-2019

\begin{tabular}{|c|c|c|c|c|c|c|c|c|}
\hline \multirow{2}{*}{$\begin{array}{l}\text { Types of } \\
\text { Disaster }\end{array}$} & \multirow{2}{*}{$\begin{array}{c}\text { Number } \\
\text { of } \\
\text { Incidents }\end{array}$} & \multicolumn{2}{|c|}{ Human Losses } & \multirow{2}{*}{$\begin{array}{c}\text { Total } \\
\text { Family } \\
\text { Affected }\end{array}$} & \multicolumn{3}{|c|}{ House Damaged } & \multirow{2}{*}{$\begin{array}{l}\text { Estimated } \\
\text { Economic } \\
\text { Lost (Nrs.) }\end{array}$} \\
\hline & & Death & Injured & & Full & Partial & Total & \\
\hline Fire & 35 & 1 & 4 & 52 & 44 & 1 & 45 & 21060735 \\
\hline Landslide & 27 & 0 & 9 & 129 & 35 & 85 & 120 & 6670000 \\
\hline $\begin{array}{l}\text { Heavy } \\
\text { Rainfall }\end{array}$ & 6 & 0 & 0 & 7 & 7 & 0 & 7 & NA \\
\hline Thunderbolt & 4 & 4 & 0 & 4 & 0 & 0 & 0 & NA \\
\hline Total & 72 & 5 & 13 & 192 & 86 & 86 & 172 & 27730735 \\
\hline
\end{tabular}

Source: $\mathrm{MoHA}, 2020$

In Dhanktua, mainly four types of disasters were recorded such as fire, landslide, heavy rainfall and thunderbolt during the period of 2017-2019. Among these, the fire incident was the main in terms of its numbers. However, on the basis of people killed, the thunderstorm was seen as the first position whereas the landslide was the next 
major disaster in terms of people injured and house damaged. Altogether, 72 different incidents were recorded from Dhankuta which killed five people and made injured 13. Similarly, 192 families were affected, 172 houses were damaged and huge economic loss due to disaster within three years at Dhankuta.

\section{Disasters in Dhankuta}

\section{Fire}

Fire is a recurring disaster in Nepal and the large numbers of incidents are reported from February to May. As per the data from MoHA 2019, fire is higher occurring incidents that shared $44.4 \%$ out of total disaster incidents in Nepal during 1971-2018. However, the number of killed by fire is negligible.

The incidents of fire in Dhankuta are similar to the national scenario where the number of incidents is highest whereas the death toll is lower however, the estimated economic losses are higher. Most of the fire incidents are caused by the negligence of people. Hunting practices, careless by a cigarette smoker, intentional fire to accelerate the growth of grasses to feed livestock and firewood collection by farmers as well as children playing with fire are possible reasons for the fire. Although, detail and careful study will be needed to identify the actual reasons. The spatial distribution of fire incidents at Dhankuta district as follows (Table 3);

Table 3: Spatial distribution of fire incidents in Dhankuta, 2017-2019

\begin{tabular}{|c|c|c|c|c|c|c|c|c|}
\hline \multirow[b]{2}{*}{ Local Levels } & \multirow{2}{*}{$\begin{array}{c}\text { Number } \\
\text { of } \\
\text { Incidents }\end{array}$} & \multicolumn{2}{|c|}{ Human Losses } & \multirow{2}{*}{$\begin{array}{c}\text { Total } \\
\text { Family } \\
\text { Affected }\end{array}$} & \multicolumn{3}{|c|}{ House Damaged } & \multirow{2}{*}{$\begin{array}{c}\text { Estimated } \\
\text { Economic } \\
\text { Lost }\end{array}$} \\
\hline & & Death & Injured & & Full & Partial & Total & \\
\hline Mahalaxmi M. & 5 & 0 & 0 & 9 & 8 & 1 & 9 & 6531940 \\
\hline $\begin{array}{l}\text { Chhathar } \\
\text { Jorpati RM. }\end{array}$ & 4 & 0 & 0 & 4 & 1 & 0 & 1 & 1348200 \\
\hline Pakhribas M. & 4 & 0 & 0 & 5 & 5 & 0 & 5 & 252500 \\
\hline Dhankuta M. & 7 & 0 & 0 & 13 & 11 & 0 & 11 & 1040000 \\
\hline $\begin{array}{l}\text { Sahidbhumi } \\
\text { RM. }\end{array}$ & 5 & 1 & 2 & 9 & 7 & 0 & 7 & 3876000 \\
\hline $\begin{array}{l}\text { Sangurigadi } \\
\text { RM. }\end{array}$ & 3 & 0 & 2 & 3 & 2 & 0 & 2 & 2110000 \\
\hline Chaubise RM. & 7 & 0 & 0 & 9 & 10 & 0 & 10 & 5902090 \\
\hline Total & 35 & 1 & 4 & 52 & 44 & 1 & 45 & 21060735 \\
\hline
\end{tabular}

Source: $\mathrm{MoHA}, 2020$

Among the local levels of Dhankuta district, Dhankuta municipality and Chaubise rural municipality had the higher cases than other local levels in terms of fire incidents. Then, Mahalaxmi municipality occurred high incidents. The reasons for spatial variation are still unknown. Then, the descending order of fire incidents has 
occurred at Sahibhumi, Chhathar Jorpati and lastly at Sangurigadi rural municipality. There were altogether 35 cases of fire incidents during 2017-2019, where one male was killed by a fire at Sahidbhumi and the other four cases were injured at different local levels. However, 52 families were affected, 44 houses were fully and one house partly damaged due to fire and it caused huge economic losses (more than 21 million) in this district. The temporal distribution of fire incidents at Dhankuta district are as follows (Table 4);

Table 4: Temporal distribution of fire incidents in Dhankuta, 2017-2019

\begin{tabular}{|c|c|c|c|c|c|}
\hline \multirow{2}{*}{ S.N. } & \multirow{2}{*}{ Local Levels } & \multicolumn{4}{|c|}{ Years and incidents of fire } \\
\hline & & 2017 & 2018 & 2019 & Total \\
\hline 1 & Mahalaxmi M. & 1 & 2 & 2 & 5 \\
\hline 2 & Chhathar Jorpati RM. & 0 & 3 & 1 & 4 \\
\hline 3 & Pakhribas M. & 0 & 1 & 3 & 4 \\
\hline 4 & Dhankuta M. & 2 & 3 & 2 & 7 \\
\hline 5 & Sahidbhumi RM. & 0 & 2 & 3 & 5 \\
\hline 6 & Sangurigadi RM. & 0 & 2 & 1 & 3 \\
\hline 7 & Chaubise RM. & 1 & 5 & 1 & 7 \\
\hline & Total & 4 & 18 & 13 & 35 \\
\hline & Percent & 11.4 & 51.4 & 37.1 & \\
\hline
\end{tabular}

Source: $\mathrm{MoHA}, 2020$

According to the yearly record, 2018 was the worst year in terms of fire incidents in Dhankuta. Altogether, more than half of the fire incidents were recorded in the 2018 year alone. But we do not forget the nature of data in the case of 2017, the data of 2017 was only included after 10 March and the incidents before this date were not included. The present local levels are formed on 10 March 2017 in Nepal which replaced the old VDCs. If we examine these incidents on a monthly basis the incidents have seemed as follows (Table 5);

Table 5: Fire incidents at Dhankuta in monthly basis, 2017-2019

\begin{tabular}{|l|r|r|r|r|r|r|r|r|r|r|r|r|}
\hline Months & Jan. & Feb. & Mar. & Apr. & May & June & July & Aug. & Sep. & Oct. & Nov. & Dec. \\
\hline $\begin{array}{l}\text { Number } \\
\text { of } \\
\text { Incidents }\end{array}$ & 2 & 2 & 8 & 2 & 0 & 2 & 2 & 1 & 2 & 4 & 5 & 5 \\
\hline
\end{tabular}

Source: $\mathrm{MoHA}, 2020$

In Dhankuta, most of the fire incidents were recorded in March which accounted more than $22 \%$ from the total incidents. March is the month of dry as well as windy season and it makes fire burning activities easier. So, the incidents of fire might be higher in this month at Dhankuta. November and December were also outnumbered 
than others. In these months, people are burning firewood to protect from severe cold and it might another cause for high incidents. However, on May no any single incident was recorded up to three years, 2017-2019. The actual reasons are unknown and need to be explored further although May is the early rainy season at Nepal which might be contributed to stop fire incidents. Similarly, the months of June to September are rainy season even though the fire incidents were recorded but the number of incidents were lower.

\section{Landslide}

Landslide is considered as the movement of earth, rock or debris towards downslope due the influence of gravity. It usually occurs as secondary effects from heavy rainfall and earthquake. Landslide is a form of mass movement where the displace materials retains its form as it moves. They become hazardous when they interfere with human activity. Great amount of money is spending for relief and recovery in recent years due to increased landslide disaster in many parts of the world (Ghimire, 2011). Landslides are very common in hills and mostly they occur in monsoon season. Heavy rainfall in the hills saturates the soil and erodes shear strength, triggering a landslide (ICIMOD, 2007). Unstable topography, steep slope and fragile nature of geological formation along with heavy monsoon rainfall make Nepal one of the most hazardous areas in the world. Landslides are the result of extreme rainfall, topography, strong earthquake and human activity. The distribution of landslide incidents at Dhankuta district as follows (Table 6);

Table 6: Spatial distribution of landslide at Dhankuta, 2017-2019

\begin{tabular}{|c|c|c|c|c|c|c|c|c|}
\hline \multirow{2}{*}{ Local Levels } & \multirow{2}{*}{$\begin{array}{c}\text { Number } \\
\text { of } \\
\text { Incidents } \\
\end{array}$} & \multicolumn{2}{|c|}{ Human Loss } & \multirow{2}{*}{$\begin{array}{c}\text { Total } \\
\text { Family } \\
\text { Affected }\end{array}$} & \multicolumn{3}{|c|}{ House Damaged } & \multirow{2}{*}{$\begin{array}{c}\text { Estimated } \\
\text { Economic } \\
\text { Lost } \\
\end{array}$} \\
\hline & & Death & Injured & & Full & Partial & Total & \\
\hline $\begin{array}{l}\text { Mahalaxmi } \\
\text { M. }\end{array}$ & 3 & 0 & 0 & 24 & 16 & 8 & 24 & 500000 \\
\hline $\begin{array}{l}\text { Chhathar } \\
\text { Jorpati RM. }\end{array}$ & 1 & 0 & 0 & 17 & 3 & 14 & 17 & $\mathrm{~N} / \mathrm{A}$ \\
\hline Pakhribas M. & 3 & 0 & 1 & 54 & 8 & 44 & 52 & N/A \\
\hline Dhankuta M. & 3 & 0 & 0 & 6 & 2 & 4 & 6 & 1570000 \\
\hline $\begin{array}{l}\text { Sahidbhumi } \\
\text { RM. }\end{array}$ & 3 & 0 & 0 & 2 & 1 & 0 & 1 & 1600000 \\
\hline $\begin{array}{l}\text { Sangurigadi } \\
\text { RM. }\end{array}$ & 7 & 0 & 5 & 19 & 3 & 11 & 14 & 540000 \\
\hline Chaubise RM. & 7 & 0 & 3 & 7 & 2 & 4 & 6 & 2460000 \\
\hline Total & 27 & 0 & 9 & 129 & 35 & 85 & 120 & 6670000 \\
\hline
\end{tabular}

Source: MoHA, 2020 
In Dhankuta, altogether 27 landslide incidents were recorded without loss of any lives of people. However, it made injured nine people, 129 families were affected and 120 houses were damaged. Also, it caused huge economic lost whereas two local levels data were not still available so, it is difficult to show the actual lost. It is remarkable that two local levels namely; Chaubise and Sangurigadi rural municipality which are laid far southern belt of the district. They are separated from Tamor River, reflected higher incidents of landslides as well as number of injured. These two local levels comprised nearly $52 \%$ out of total landslides and more than $88 \%$ out of total injured people in this district. ICIMOD (2007) argues that the event of landslide is contributed by high relief and steep slopes, unstable geology and concentrated rainfall naturally in one hand. On the other hand, human factors such as deforestation, improper land use and construction and agriculture activities on hill slopes are also other factors for landslides. Similar results also found by Sharma (2013) to examine the five years landslides in Nepal. He claimed that more than $60 \%$ landslides and more than $63 \%$ of death are concentrated at Hill region of Nepal. The temporal distribution of the landsides is given in Table 7.

Table 7: Temporal distribution of landslides at Dhankuta, 2017-2019

\begin{tabular}{|c|l|r|r|r|r|}
\hline \multirow{2}{*}{ S.N. } & \multirow{2}{*}{ Local Levels } & \multicolumn{4}{|c|}{ Years and incidents of fire } \\
\cline { 3 - 6 } & & $\mathbf{2 0 1 7}$ & $\mathbf{2 0 1 8}$ & $\mathbf{2 0 1 9}$ & \multicolumn{1}{c|}{ Total } \\
\hline 1 & Mahalaxmi M. & 0 & 0 & 3 & 3 \\
\hline 2 & Chhathar Jorpati RM. & 0 & 0 & 1 & 1 \\
\hline 3 & Pakhribas M. & 0 & 0 & 3 & 3 \\
\hline 4 & Dhankuta M. & 0 & 0 & 3 & 3 \\
\hline 5 & Sahidbhumi RM. & 0 & 0 & 3 & 3 \\
\hline 6 & Sangurigadi RM. & 0 & 1 & 6 & 7 \\
\hline 7 & Chaubise RM. & 0 & 0 & 7 & 7 \\
\hline \multicolumn{2}{|l|}{ Total } & 0 & 1 & 26 & 27 \\
\hline
\end{tabular}

Source: $\mathrm{MoHA}, 2020$

In Dhankuta district, almost the landslides were recorded in 2019 because the major cause of the landslide was rainfall and the representative of local levels informed that the rainfall was comparatively little in Dhankuta in the year of 2017 and 2018. In comparison to other years, 2019 received higher rainfall in Dhankuta. ICIMOD (2007) explained that rainfall is the landslide triggers in most cases. In addition, Sharma (2013) also concluded that continuous rainfall is the major cause of landslides in Nepal. Generally, the landslide incidents occurred in the rainy season and the landslide distribution in terms of monthly basis is given in table 8 . 
Table 8: Landslides incidents at Dhankuta in monthly basis, 2017-2019

\begin{tabular}{|l|c|c|c|c|}
\hline Months & July & September & October & \multicolumn{1}{c|}{ Total } \\
\hline Number of Incidents & 24 & & 1 & 27 \\
\hline
\end{tabular}

Source: $\mathrm{MoHA}, 2020$

Most of the landslide incidents were recorded in the month of July which shared more than $88 \%$ of the total landslides. In addition, September and October have also some incidents of the landslide in this district. Obviously, the causes were connected with rainfall. In Nepal, most of the rainfall were received in the month of July as a result, the landslide incidents were also high in July.

\section{Heavy rainfall}

Heavy rainfall is extreme precipitation within a short period of time which creates severe floods, landslides and erosion, particularly in a steep slope. So, it is dangerous because of the suddenness and rapid with which they occur without warning. It triggers various hazards such as flash flood, landslide, Glacial Lake Outburst Flood (GLOF), failure of a dam in one hand. On the other hand, it also deposits lots of sedimentation in the lower part where the topography is slightly gentle. The spatial distribution of heavy rainfall as follows (Table 9);

Table 9: Spatial distribution of heavy rainfall at Dhanktua, 2017-2019

\begin{tabular}{|c|c|c|c|c|c|c|c|c|}
\hline \multirow{2}{*}{$\begin{array}{l}\text { Local } \\
\text { Levels }\end{array}$} & \multirow{2}{*}{$\begin{array}{c}\text { Number } \\
\text { of } \\
\text { Incidents }\end{array}$} & \multicolumn{2}{|c|}{ Death } & \multirow{2}{*}{$\begin{array}{c}\text { Total } \\
\text { Family } \\
\text { Affected }\end{array}$} & \multicolumn{3}{|c|}{ House Damaged } & \multirow{2}{*}{$\begin{array}{c}\text { Estimated } \\
\text { Economic } \\
\text { Lost }\end{array}$} \\
\hline & & Death & Injured & & Full & Partial & Total & \\
\hline Mahalaxmi M. & 3 & 0 & 0 & 3 & 3 & 0 & 3 & NA \\
\hline $\begin{array}{l}\text { Chhathar } \\
\text { Jorpati RM. }\end{array}$ & 0 & 0 & 0 & 0 & 0 & 0 & 0 & 0 \\
\hline Pakhribas M & 1 & 0 & 0 & 2 & 2 & 0 & 2 & NA \\
\hline Dhankuta M. & 0 & 0 & 0 & 0 & 0 & 0 & 0 & 0 \\
\hline $\begin{array}{l}\text { Sahidbhumi } \\
\text { RM. }\end{array}$ & 0 & 0 & 0 & 0 & 0 & 0 & 0 & 0 \\
\hline $\begin{array}{l}\text { Sangurigadi } \\
\text { RM. }\end{array}$ & 1 & 0 & 0 & 1 & 1 & 0 & 1 & NA \\
\hline Chaubise RM. & 1 & 0 & 0 & 1 & 1 & 0 & 1 & NA \\
\hline Total & 6 & 0 & 0 & 7 & 7 & 0 & 7 & 0 \\
\hline
\end{tabular}

Source: $\mathrm{MoHA}, 2020$

Altogether, 6 incidents of heavy rainfall have recorded at Dhankuta. Out of these, $50 \%$ have occurred at Mahalaxmi municipality and the other three local levels namely Pakhribas municipality, Sangurigadi and Chaubise rural municipality have 
one incident each. Remaining two local levels have no record of incidents. Due to heavy rainfall, seven families were affected and the same number of houses have completely damaged. Heavy rainfall does not create any disaster directly but it causes to increase in the water level in streams, canals and rivers then the waters start to flow outside from the limited way and it damaged the crops, properties, lives and livelihood of people. It is remarkable that whole incidents due to heavy rainfall occurred in 2019. No, the incident was recorded in the year 2017 and 2018. In Nepal, generally, most of the rainfall is occurred in June to September (Sharma, 2013) and this result also equivalent at Dhanktua too because more than $66 \%$ heavy rainfall incidents were recorded in July (4), $17 \%$ in September (1) and 17\% in October (1). Hence, July was the more vulnerable month in terms of heavy rainfall at Dhankuta.

\section{Thunderbolt}

Thunderbolt is another important disaster in the Dhankuta district. However, this is not coming in a countable figure at the national level. The incidents of thunderbolt were very low although the number of people killed by this incident was higher. Altogether, four people were killed by this which shared $80 \%$ of the total death due to disasters in Dhankuta. Thunderbolt details in the Dhankuta district are given in table 10 .

Table 10: Thunderbolt incidents in Dhankuta, 2017-2019

\begin{tabular}{|c|l|r|r|r|r|}
\hline & & \multirow{2}{*}{$\begin{array}{c}\text { Number of } \\
\text { S.N. }\end{array}$} & Local Levels & \multirow{2}{*}{$\begin{array}{c}\text { Human loss } \\
\text { Incidents }\end{array}$} & Total \\
\cline { 5 - 6 } & & & Death & Injured & $\begin{array}{c}\text { Family } \\
\text { Affected }\end{array}$ \\
\hline 1 & Mahalaxmi M. & 2 & 2 & 0 & 2 \\
\hline 2 & Chhathar Jorpati RM. & 0 & 0 & 0 & 0 \\
\hline 3 & Pakhribas M. & 1 & 1 & 0 & 1 \\
\hline 4 & Dhankuta M. & 0 & 0 & 0 & 0 \\
\hline 5 & Sahidbhumi RM. & 0 & 0 & 0 & 0 \\
\hline 6 & Sangurigadi RM. & 1 & 1 & 0 & 1 \\
\hline 7 & Chaubise RM. & 0 & 0 & 0 & 0 \\
\hline & Total & 4 & 4 & 0 & 4 \\
\hline
\end{tabular}

Source: $\mathrm{MoHA}, 2020$

Altogether, four incidents were recorded from 2017 to 2019 in the Dhankuta district. Among these, Mahalaxmi municipality seemed more affected local level at the Dhankuta district. At this local level, $50 \%$ of people were killed due to thunderbolt whereas at Pakhribas municipality and Sangurigadi have killed one at each local level. Remaining four local levels have not recorded any incidents from the thunderbolt. 
Out of these thunderbolts, three incidents were occurred in 2018 and one was 2019. So, the year of 2018 was highly affected by a thunderbolt in Dhankuta. According to the recent data, the month of April was seen more vulnerable because $50 \%$ of incidents occurred in April. In addition, in the month of March and July one incident was recorded in each.

\section{Conclusion}

Disasters are unavoidable situations but can reduce the loss of lives and physical property through good preparedness. The success of response and relief efforts depends upon the degree of preparedness. Well preparedness is only possible with reliable data and information which support for prediction in days to come. Every disaster has a temporal dimension and relative to that is its predictability or unpredictability. In this context, this paper briefly reflected the spatial and temporal distribution of disasters in a lucid way at Dhankuta district which covered the duration of 2017-2019. The impact of the disaster is exacerbated by the lack of preparedness and the absence of measures for mitigating their impacts. According to the disaster data of this district, mostly it is experiencing fire, landslide, heavy rainfall and thunderbolt disaster during 20172019. Out of these, fire incidents were mostly occurred in the month of March (22 $\%$ ), landslides in July (88 \%), heavy rainfall in July (67\%) and thunderbolt in April (50\%). Similarly, fire incidents were mostly concentrated at Dhankuta municipality and Chaubise rural municipality. However, landslides were concentrated at Chaubise and Sangaurigadi rural municipality and the and heavy rainfall and thunderbolts were at Mahalaxmi municipality. There is a positive relationship between the heavy rainfall and the incidents of a landslide because $96 \%$ of landslides were recorded in the year of 2019 and entire heavy rainfall incidents were also recorded the same year. Another interesting fact also revealed from this data is that most of these two events were recorded in the month of July.

\section{References}

Bankoff, G. (2004). The Historical Geography of Disaster:Vulenerability and Local knowledge in western discourse (First ed.). (G. Bankoff, G. Frerks, \& D. Hilhorst, Eds.) London, sterling, VA: EARTHSCAN.

Francis, A. (2020). Climate Induced Migration and Free Movement agreements . Journal of International Affairs, 73(1), 123-134.

Gajanayakea, A., Mohsenia, H., Zhanga, G., Mullettb, J., \& Setunge, S. (2018). Community adaptation to cope with disaster related road structure. ScienceDirect, 1355-1362. Retrieved from www.sciencedirect.com

Gautam, D. (2017). Assessment of social vulnerability to natural hazards in Nepal. Natural Hazards and Earth System Sciences, 17(12), 2313-2320. https://doi. org/10.5194/nhess-17-2313-2017 
Ghimire, M. (2011). Landslide cccurrence and its relation with terrain factors in the Siwalik Hills Nepal: case study of susceptibility assessment in three basin. Nat Hazard, 56, 299-320. doi:10.1007/s11069-010-9569-7

Hyndman, D., \& Hyndman, D. (2017). Natural Hazards and Disasters (Fifth ed.). Boston, USA: CENGAGE Learning.

ICIMOD. (2007). Disaster Preparedness for Natural Hazards: Current Status in Nepal. Kathmandu, Nepal: International Centre for Integrated Mountain Development (ICIMOD).

Keller, E. A., Devecchio, D. E., \& Clague, J. J. (2015). Natural Hazards Earth's Processes as Hazards, Disasters and Catastrophes (THIRD CANADIAN EDITION ed.). Toronto: PEARSON.

Khanal, N. R. (1996). Assessment of Natural Hazards in Nepal A Research Report Submitted to the Research Division, Tribhuvan University. Kathmandu, Nepal.

Khanal, N. R., Shrestha, M., \& Ghimire, M. (Eds.). (2007). Preparing for Flood Disaster Mapping and Assessing Hazard in the Ratu Watershed, Nepal. Kathmandu, Nepal: ICIMOD \& UNESCO.

Leroy, S. A. G. (2006). From natural hazard to environmental catastrophe: Past and present. Quaternary International, 158(1), 4-12. https://doi.org/10.1016/j. quaint.2006.05.012

Linkha, T.R. (2018). Local Level Re-stucture in Nepal: An Example of Dhankuta District. Baouddhik Abhiyan (A Multidisciplinary Research Journal). Nepal Progressive Professors`Association, Provincial Committee, Province No. One, $6,153-165$.

LLRC (2073). Terms of Reference (ToR) of Local Level Restructuring Technical Support

Committee. Local Level Restructuring Commission, Kathmandu, Nepal.

Mitchell, J. T., Borden, K. A., \& Schmidtlein, M. C. (2008). Teaching Hazards Geography and Geographic Information System: A Middle School Level Experience. International Research in Geographical and Environmental Educaiton. doi:10.2167/irgee234.0

MoHA (2017). Nepal Disaster Report 2018. Government of Nepal, Ministry of Home Affairs.

MoHA (2019). Nepal Disaster Report 2019. Governemnt of Nepal, Ministry of Homa Affairs.

MoHA(2020). Nepal Disaster Risk Reduction Portal (www.drrportal.gov.np) extracted on 11 January, 2020.

Pearce, L. (2003). Disaster management and community planning, and public participation: How to achieve sustainable hazard mitigation. Natural Hazards, 28(2-3), 211-228. https://doi.org/10.1023/A:1022917721797 
Practical Action (2010). Understanding Disaster Management in Practice: with reference to Nepal. Kathmandu, Nepal

Sharma Pangali, T. P. (2013). Landslide Hazard in Nepal. (H. L. Koirala, P. S. Chapagain, B. Adhikari, \& D. K. Rai, Eds.) The Geographic Base, 5, 54-60.

Shrestha, B. (2005). Recurrence of Natural Hazards A challenge for Managment in Nepal. (M. P. Tripathi, D. B. Lamichhane, \& K. R. Bastola, Eds.) The Himalayan Geographers, 4 \& 5, 8-16.

Wisner, B., Blaikie, P., Cannon, T., \& Davis, I. (2005). At Risk Natural hazards, People's Vulnerability and Disasters (Second ed.). London and Newyork: Routledge Taylor and Fransis Group. 